\title{
Theoretical and mathematical models of the torque of mechanical losses in a hydraulic rotational motor for hydrostatic drive
}

\author{
Zygmunt Paszota, Prof. \\ Gdansk University of Technology
}

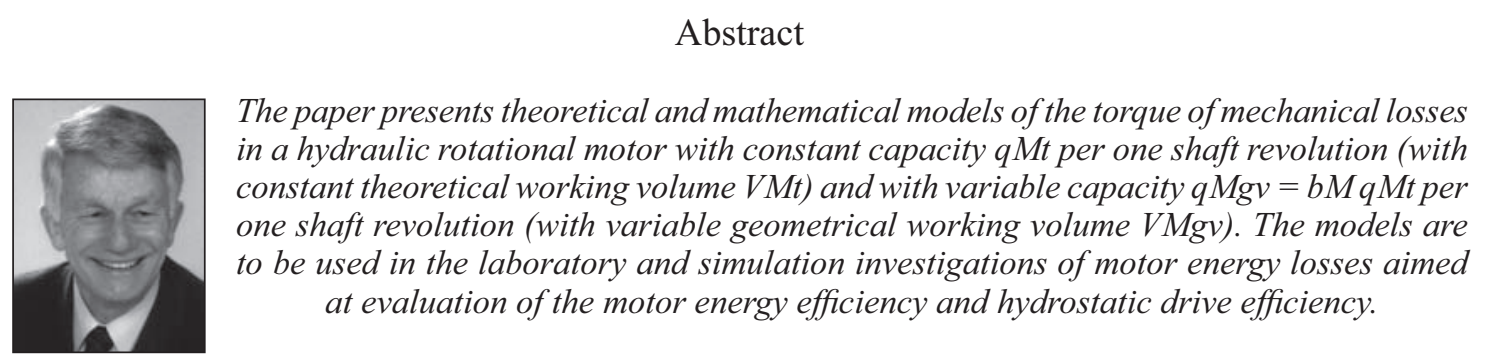

Keywords: hydrostatic drive; hydraulic motor; energy efficiency

\section{INTRODUCTION}

The paper is a continuation of references $[1 \div 10]$, aimed at developing a method of evaluation of the losses and energy efficiency of the hydrostatic drives and displacement machines used in them. The method is based on theoretical and mathematical descriptions of losses in the pumps, hydraulic motors and in other elements of a hydrostatic drive system.

Description of the hydraulic motor losses and energy efficiency is based on the diagram of the direction of increasing power stream in a rotational hydraulic motor, which is introduced instead of the Sankey diagram (Fig.1 [10]).

The aim of the paper is to present theoretical and mathematical models of torque of mechanical losses in the rotational hydraulic motor "shaft - working chambers" assembly. The motor is a displacement machine with constant theoretical capacity $\mathrm{q}_{\mathrm{Mt}}$ per one shaft revolution (with constant motor theoretical working volume $\mathrm{V}_{\mathrm{Mt}}$ ) or with variable geometrical capacity $\mathrm{q}_{\mathrm{Mgv}}=\mathrm{b}_{\mathrm{M}} \mathrm{q}_{\mathrm{Mt}}$ per one shaft revolution (with variable motor geometrical working volume $\mathrm{V}_{\mathrm{Mgv}}$ ).

The models are to be used in the laboratory and simulation investigation of the motor energy losses, motor energy efficiency and hydrostatic drive efficiency.

\section{THEORETICAL MODELS OF THE} TORQUE $M_{M m}$ OF MECHANICAL LOSSES

IN THE MOTOR ,SHAFT - WORKING CHAMBERS" ASSEMBLY

Torque $M_{\mathrm{Mi}}$ indicated in the rotational hydraulic motor working chambers must be greater than torque $M_{M}$ loading the motor shaft (torque required by the driven machine (device)) because of the necessity of balancing also the torque $M_{M m}$ of mechanical losses in the ,shaft - working chambers" assembly. The assembly connects the shaft with working chambers, forms the working chambers and changes their capacity. Therefore, the torque $\mathrm{M}_{\mathrm{Mi}}$ indicated in the motor working chambers is a sum of torque $\mathrm{M}_{\mathrm{M}}$ loading the shaft and of torque $\mathrm{M}_{\mathrm{Mm}}$ of mechanical losses:

$$
\mathrm{M}_{\mathrm{Mi}}=\mathrm{M}_{\mathrm{M}}+\mathrm{M}_{\mathrm{Mm}}
$$

Torque $\mathrm{M}_{\mathrm{Mm}}$ of mechanical losses in a rotational hydraulic motor with variable geometrical capacity $\mathrm{q}_{\mathrm{Mgv}}$ per one shaft revolution is, with maximum value of $\mathrm{q}_{\mathrm{Mgv}}$, i.e. with $\mathrm{q}_{\mathrm{Mgv}}=$ $\mathrm{q}_{\mathrm{Mt}}$ (with coefficient $\mathrm{b}_{\mathrm{M}}=\mathrm{q}_{\mathrm{Mgv}} / \mathrm{q}_{\mathrm{Mt}}=1$ ), equal to the torque of mechanical losses in the motor working with constant theoretical capacity $\mathrm{q}_{\mathrm{Mt}}$ per one shaft revolution. The theoretical and mathematical models describing the torque $\mathrm{M}_{\mathrm{Mm}}$ of mechanical losses in the ,shaft - working chambers" assembly of a motor with variable capacity $\mathrm{q}_{\mathrm{Mgv}}$ per one shaft revolution (with variable $b_{M}$ coefficient) may be described with reference to models of the torque $\mathrm{M}_{\mathrm{Mm}}$ of mechanical losses in the assembly of a motor with constant capacity $\mathrm{q}_{\mathrm{Mt}}$ per one shaft revolution (with $\mathrm{b}_{\mathrm{M}}=1$ ).

Torque $M_{M m}$ of mechanical losses in a rotational hydraulic motor is mainly an effect of friction forces between elements of the "shaft - working chambers" assembly, dependent, among others, on the torque $M_{M}$ loading the shaft.

Friction forces between the elements of the "shaft - working chambers" assembly are, to some extent, an effect of loading those elements by inertia forces from the rotational and reciprocating motion, dependent on the shaft rotational speed $n_{M}$ and on the motor capacity $q_{M g v}$ per one shaft revolution $\left(b_{M}\right.$ coefficient). 
There are also friction forces between the "shaft - working chambers" assembly elements and the working fluid, dependent on the fluid viscosity $v$ and on the shaft rotational speed $n_{M}$ and also on the motor capacity $q_{M g v}$ per one shaft revolution ( $b_{\mathrm{M}}$ coefficient). The impact of working fluid viscosity $v$ on the friction forces between elements of the „shaft - working chambers" assembly and the working fluid is visible mainly in the piston hydraulic motors with casing filled with fluid.

Torque $\mathrm{M}_{\mathrm{M}}$ loading the motor shaft and the shaft rotational speed $n_{M}$ required by the driven machine (device) change in the $\left(0 \leq \bar{\omega}_{\mathrm{M}}<\bar{\omega}_{\mathrm{Mmax}}, 0 \leq \overline{\mathrm{M}}_{\mathrm{M}}<\overline{\mathrm{M}}_{\mathrm{M} \max }\right)$ hydrostatic drive operating range. The kinematic viscosity $v$ of working fluid (hydraulic oil, oil - water emulsion) changes in the $v_{\min } \leq v \leq v_{\max }$ range.

$\mathrm{M}_{\mathrm{M}}, \mathrm{n}_{\mathrm{M}}$ and $v$ are parameters independent of the motor and of the losses in that motor. In models applied to motor with variable capacity $\mathrm{q}_{\mathrm{Mgv}}=\mathrm{b}_{\mathrm{M}} \mathrm{q}_{\mathrm{Mt}}$ per one shaft revolution, the change of $\mathrm{q}_{\mathrm{Mgv}}\left(\mathrm{b}_{\mathrm{M}}\right)$ is assumed in the $0 \leq \mathrm{q}_{\mathrm{Mgv}} \leq \mathrm{q}_{\mathrm{Mt}}\left(0 \leq \mathrm{b}_{\mathrm{M}} \leq 1\right)$ range, although in fact $b_{\mathrm{Mmin}}$ is of the $0.2 \div 0.3$ order.

Torque $\mathrm{M}_{\mathrm{Mm} \mid \mathrm{M}_{\mathrm{M}}, \mathrm{n}_{\mathrm{M}}, \mathrm{b}_{\mathrm{M}},{ }^{,}}$of mechanical losses in a hydraulic motor operating with torque $\mathrm{M}_{\mathrm{M}}$ and speed $\mathrm{n}_{\mathrm{M}}$ required by the driven machine (device) (the motor having capacity $\mathrm{q}_{\mathrm{Mgv}}$ per one shaft revolution ( $b_{M}$ coefficient) and fed with working fluid of

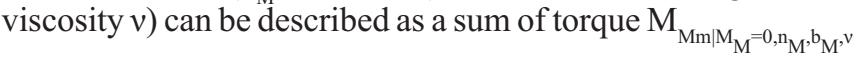
and increase $\Delta \mathrm{M}_{\mathrm{Mm} \mid \mathrm{M}_{\mathrm{M}},{ }_{\mathrm{M}},{ }^{,} \mathrm{M}^{,},{ }}$; torque $\mathrm{M}_{\mathrm{Mm} \mid \mathrm{M}_{\mathrm{M}}=0, \mathrm{n}_{\mathrm{M}}, \mathrm{b}_{\mathrm{M}}, v}$ of mechanical losses occurs in an unloaded motor (when the torque $\mathrm{M}_{\mathrm{M}}$ required of the motor is equal to zero $-\mathrm{M}_{\mathrm{M}}=0$ ) and

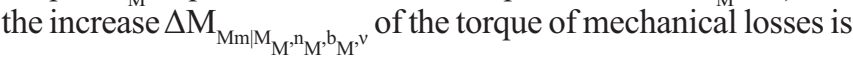
an effect of loading the ,shaft - working chambers” assembly elements by the increasing shaft loading torque $M_{M}$ :

$$
\begin{gathered}
\Delta \mathrm{M}_{\mathrm{Mm} \mid \mathrm{M}_{\mathrm{M}}, \mathrm{n}_{\mathrm{M}}, \mathrm{b}_{\mathrm{M}}, v}=\mathrm{M}_{\mathrm{Mm} \mid \mathrm{M}_{\mathrm{M}}=0, \mathrm{n}_{\mathrm{M}}, \mathrm{b}_{\mathrm{M}^{, v}}}+ \\
+\Delta \mathrm{M}_{\mathrm{Mm} \mid \mathrm{M}_{\mathrm{M}},{ }^{, \mathrm{n}, \mathrm{b}_{\mathrm{M}}, v}}
\end{gathered}
$$

In constructing the theoretical and mathematical models describing the torque $\Delta \mathrm{M}_{\mathrm{Mm} \mid \mathrm{M}_{\mathrm{M}}, \mathrm{n}_{\mathrm{M}},{ }_{\mathrm{M}},{ }^{, v}}$ of mechanical losses in a rotational hydraulic motor, an assumption is made that the

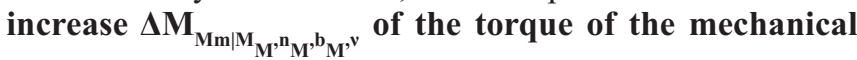
losses in the „shaft - working chambers" assembly, as an effect of the increasing required torque $M_{M}$ loading the motor shaft, is practically independent of:

- required shaft rotational speed $\mathbf{n}_{\mathrm{M}}$,

- value of the $b_{M}=q_{M g v} / q_{M t}$ coefficient of capacity per one shaft revolution,

- working fluid viscosity $v$.

An assumption was also made in the proposed models, that increase $\Delta M_{M m \mid M_{M}, n_{M}, b_{M}, v}$ of the torque of the mechanical losses is determined at the speed $n_{M}=n_{M t}$ i.e. equal to the motor shaft theoretical speed, at the coefficient $b_{M}=1$ (with $q_{M g v}=q_{M t}$ ) and at $v=v_{n}$ i.e. working fluid reference viscosity $v_{n}$ :

$$
\begin{aligned}
& \Delta \mathrm{M}_{\mathrm{Mm} \mid \mathrm{M}_{\mathrm{M}}, \mathrm{n}_{\mathrm{M}}, \mathrm{b}_{\mathrm{M}}, v}=\mathrm{f}\left(\mathrm{M}_{\mathrm{M}}\right)= \\
& =\Delta \mathrm{M}_{\mathrm{Mm} \mid \mathrm{M}_{\mathrm{M}}, \mathrm{n}_{\mathrm{Mt}}, \mathrm{b}_{\mathrm{M}}=1, v_{\mathrm{n}}} \sim \mathrm{M}_{\mathrm{M}}
\end{aligned}
$$

In constructing the theoretical and mathematical models

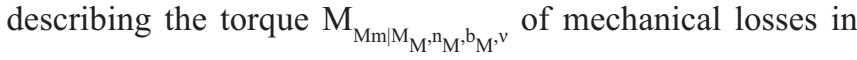
the „shaft - working chambers” assembly it was also assumed that:
- the impact of required shaft rotational speed $n_{M}$ and value of the coefficient $b_{M}=q_{M g v} / q_{M t}$ on the load of the assembly elements with inertia forces,

- the impact of working fluid viscosity $v, n_{M}$ and $b_{M}$ on the friction forces between elements and working fluid,

in consequence, the impact of $n_{M}, b_{M}$ and $v$ on the torque $M_{M m}$ of mechanical losses in the motor can be determined with the shaft loading torque equal to zero $\left(M_{M}=0\right)$, because the inertia forces of the assembly elements and friction forces between the elements and working fluid are independent of the torque $M_{M}$ loading the motor shaft:

$$
\mathrm{M}_{\mathrm{Mm} \mid \mathrm{M}_{\mathrm{M}}=0, \mathrm{n}_{\mathrm{M}}, \mathrm{b}_{\mathrm{M}}, v}=\mathrm{f}\left(\mathrm{n}_{\mathrm{M}}, \mathrm{b}_{\mathrm{M}}, v\right)
$$

The above mentioned assumptions allow to describe the torque $\mathrm{M}_{\mathrm{Mm} \mid \mathrm{M}_{\mathrm{M}},{ }^{,} \mathrm{M}^{,},{ }_{\mathrm{M}}, \mathrm{v}}$ of mecha-nical losses in the ,shaft - working chambers" assembly by a theoretical model in the form:

$$
\begin{gathered}
\mathrm{M}_{\mathrm{Mm} \mid \mathrm{M}_{\mathrm{M}}, \mathrm{n}_{\mathrm{M}}, \mathrm{b}_{\mathrm{M}^{, v}}}=\mathrm{M}_{\mathrm{Mm} \mid \mathrm{M}_{\mathrm{M}}=0, \mathrm{n}_{\mathrm{M}}, \mathrm{b}_{\mathrm{M}}, v}+ \\
+\Delta \mathrm{M}_{\mathrm{Mm} \mid \mathrm{M}_{\mathrm{M}}, \mathrm{n}_{\mathrm{Mt}}, \mathrm{b}_{\mathrm{M}}=1, v_{\mathrm{n}}}
\end{gathered}
$$

In a hydraulic motor with theoretical (constant) capacity $\mathrm{q}_{\mathrm{Mt}}$ per one shaft revolution $\left(\mathrm{b}_{\mathrm{M}}=1\right)$, operating with theoretical (constant) shaft rotational speed $\mathrm{n}_{\mathrm{Mt}}$ and the working fluid reference (constant) viscosity $v_{n}$, the theoretical model describing the torque of mechanical losses in the assembly takes the form (Fig.1):

$$
\begin{gathered}
\mathrm{M}_{\mathrm{Mm} \mid \mathrm{M}_{\mathrm{M}}, \mathrm{n}_{\mathrm{Mt}}, \mathrm{b}_{\mathrm{M}}=1, v_{\mathrm{n}}}=\mathrm{M}_{\mathrm{Mm} \mid \mathrm{M}_{\mathrm{M}}=0, \mathrm{n}_{\mathrm{Mt}}, \mathrm{b}_{\mathrm{M}}=1, v_{\mathrm{n}}}+ \\
+\Delta \mathrm{M}_{\mathrm{Mm} \mid \mathrm{M}_{\mathrm{M}}, \mathrm{n}_{\mathrm{Mt}}, \mathrm{b}_{\mathrm{M}}=1, \mathrm{v}_{\mathrm{n}}}
\end{gathered}
$$

The impact of inertia forces of the ,shaft - working chambers" assembly elements performing the rotational and reciprocating motion on the torque $M_{M m \mid M_{M}=0, n_{M^{,}}, b_{M^{,}}, v}$ of mechanical losses in an unloaded motor may be presented as a function of the motor shaft rotational speed $\mathbf{n}_{\mathrm{M}}$ and as a function of geometrical capacity $q_{M g v}\left(b_{M}\right.$ coefficient $)$ per one shaft revolution.

The impact of the friction forces between the „shaft - working chambers" assembly elements and the working fluid on the torque $\mathbf{M}_{\mathrm{Mm} \mid \mathrm{M}_{\mathrm{M}}=0, \mathrm{n}_{\mathrm{N}^{,}}{ }^{\mathrm{b}} \mathrm{v}^{, v}}$ of the mechanical losses in an unloaded motor may be presented as a function of the working fluid viscosity $v$ and as a function of the motor shaft rotational speed $n_{M}$ and of the capacity $q_{M g v}$ (coefficient $b_{M}$ ) per one shaft revolution.

The proposed theoretical models describing the torque $\mathbf{M}_{\mathrm{Mm} \mid \mathbf{M}_{M}=0, \mathbf{n}_{M^{,}, b_{M}, v}}$ of mechanical losses in the ,shaft - working chambers" assembly of an unloaded hydraulic motor (with torque $M_{M}=0$ ), with changing shaft speed $n_{v}$, with theoretical (constant) capacity $\mathrm{q}_{\mathrm{Mt}}\left(\mathrm{b}_{\mathrm{M}}=1\right)$ or geometrical (variable) capacity $q_{\mathrm{Mgv}}\left(b_{\mathrm{M}}\right)$ of the motor per one shaft revolution and with changing working fluid viscosity $v$, take the form:

- in a hydraulic motor with theoretical (constant) capacity $\mathrm{q}_{\mathrm{Mt}}\left(\mathrm{b}_{\mathrm{M}}=1\right.$ ) per one shaft revolution (Fig. 2):

$$
\mathrm{M}_{\mathrm{Mm} \mid \mathrm{M}_{\mathrm{M}}=0, \mathrm{n}_{\mathrm{M}}, \mathrm{b}_{\mathrm{M}}=1, v}=\mathrm{M}_{\mathrm{Mm} \mid \mathrm{M}_{\mathrm{M}}=0, \mathrm{n}_{\mathrm{M}}, \mathrm{b}_{\mathrm{M}}=1, v_{\mathrm{n}}}\left(\frac{v}{v_{\mathrm{n}}}\right)^{\mathrm{a}_{\mathrm{vm}}}=
$$$$
=\left(\mathrm{M}_{\mathrm{Mm} \mid \mathrm{M}_{\mathrm{M}}=0, \mathrm{n}_{\mathrm{M}}=0, \mathrm{~b}_{\mathrm{M}}=1, v_{\mathrm{n}}}+\Delta \mathrm{M}_{\mathrm{Mm} \mid \mathrm{M}_{\mathrm{M}}=0, \mathrm{n}_{\mathrm{M}}, \mathrm{b}_{\mathrm{M}}=1, v_{\mathrm{n}}}\right)\left(\frac{v}{v_{\mathrm{n}}}\right)^{\mathrm{a}_{\mathrm{vm}}}
$$ 
where:

$$
\begin{gathered}
\Delta \mathrm{M}_{\mathrm{Mm} \mid \mathrm{M}_{\mathrm{M}}=0, \mathrm{n}_{\mathrm{M}}, \mathrm{b}_{\mathrm{M}}=1, v_{\mathrm{n}}}=\mathrm{M}_{\mathrm{Mm} \mid \mathrm{M}_{\mathrm{M}}=0, \mathrm{n}_{\mathrm{M}}, \mathrm{b}_{\mathrm{M}}=1, v_{\mathrm{n}}}+ \\
-\mathrm{M}_{\mathrm{Mm} \mid \mathrm{M}_{\mathrm{M}}=0, \mathrm{n}_{\mathrm{M}}=0, \mathrm{~b}_{\mathrm{M}}=1, v_{\mathrm{n}}}=
\end{gathered}
$$

$$
=\left(M_{M m \mid M_{M}=0, n_{M}=n_{M t}, b_{M}=1, v_{n}}-M_{M m \mid M_{M}=0, n_{M}=0, b_{M}=1, v_{n}}\right) \frac{n_{M}}{n_{M t}}
$$

- in a hydraulic motor with geometrical (variable) capacity $\mathrm{q}_{\mathrm{Mgv}}\left(\mathrm{q}_{\mathrm{Mgv}}=\mathrm{b}_{\mathrm{M}} \mathrm{q}_{\mathrm{Mt}}\right)$ per one shaft revolution (Fig. 5):

$$
\begin{gathered}
M_{M m \mid M_{M}=0, n_{M}, b_{M}, v}=M_{M m \mid M_{M}=0, n_{M}, b_{M}, v_{n}}\left(\frac{v}{v_{n}}\right)^{a_{v m}}= \\
=\left(M_{M m \mid M_{M}=0, n_{M}=0, b_{M}=0, v_{n}}+\Delta M_{M m \mid M_{M}=0, n_{M}, b_{M}, v_{n}}\right)\left(\frac{v}{v_{n}}\right)^{a_{v m}} \\
=\left(M_{M m \mid M_{M}=0, n_{M}=0, b_{M}=1, v_{n}}+\Delta M_{M m \mid M_{M}=0, n_{M}, b_{M}, v_{n}}\right)\left(\frac{v}{v_{n}}\right)^{a_{v m}}
\end{gathered}
$$

where:

$$
\begin{gathered}
\Delta \mathrm{M}_{\mathrm{Mm} \mid \mathrm{M}_{\mathrm{M}}=0, \mathrm{n}_{\mathrm{M}}, \mathrm{b}_{\mathrm{M}}, v_{\mathrm{n}}}=\mathrm{M}_{\mathrm{Mm} \mid \mathrm{M}_{\mathrm{M}}=0, \mathrm{n}_{\mathrm{M}}, \mathrm{b}_{\mathrm{M}}, v_{\mathrm{n}}}+ \\
-\mathrm{M}_{\mathrm{Mm} \mid \mathrm{M}_{\mathrm{M}}=0, \mathrm{n}_{\mathrm{M}}=0, \mathrm{~b}_{\mathrm{M}}=0, v_{\mathrm{n}}}= \\
=\mathrm{M}_{\mathrm{Mm} \mid \mathrm{M}_{\mathrm{M}}=0, \mathrm{n}_{\mathrm{M}}, \mathrm{b}_{\mathrm{M}, v_{\mathrm{n}}}}-\mathrm{M}_{\mathrm{Mm} \mid \mathrm{M}_{\mathrm{M}}=0, \mathrm{n}_{\mathrm{M}}=0, \mathrm{~b}_{\mathrm{M}}=1, v_{\mathrm{n}}}= \\
=\left(\mathrm{M}_{\mathrm{Mm} \mid \mathrm{M}_{\mathrm{M}}=0, \mathrm{n}_{\mathrm{M}}=\mathrm{n}_{\mathrm{Mt}}, \mathrm{b}_{\mathrm{M}}=1, v_{\mathrm{n}}}-\mathrm{M}_{\mathrm{Mm} \mid \mathrm{M}_{\mathrm{M}}=0, \mathrm{n}_{\mathrm{M}}=0, \mathrm{~b}_{\mathrm{M}}=1, v_{\mathrm{n}}}\right) \frac{\mathrm{n}_{\mathrm{M}}}{\mathrm{n}_{\mathrm{Mt}}} \mathrm{b}_{\mathrm{M}}
\end{gathered}
$$

It is assumed in expressions (9) and (10) that the torque

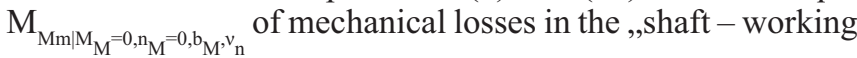
chambers" assembly of an unloaded hydraulic motor $\left(\mathrm{M}_{M}=0\right)$ with geometrical (variable) capacity $\mathrm{q}_{\mathrm{Mgv}}\left(\mathrm{q}_{\mathrm{Mgv}}=\mathrm{b}_{\mathrm{M}} \mathrm{q}_{\mathrm{M}}\right.$ ) per one shaft revolution and with zero shaft rotational speed $\left(\mathrm{n}_{\mathrm{M}}=0\right)$ is practically independent of the coefficient $b_{\mathrm{M}}$ of capacity per one shaft revolution and can be determined for $b_{M}=1$. Therefore the following simplifying assumption is accepted:

$$
\begin{gathered}
\mathrm{M}_{\mathrm{Mm} \mid \mathrm{M}_{\mathrm{M}}=0, \mathrm{n}_{\mathrm{M}}=0, \mathrm{~b}_{\mathrm{M}}=0, v_{\mathrm{n}}}=\mathrm{M}_{\mathrm{Mm} \mid \mathrm{M}_{\mathrm{M}}=0, \mathrm{n}_{\mathrm{M}}=0, \mathrm{~b}_{\mathrm{M}}, v_{\mathrm{n}}}= \\
=\mathrm{M}_{\mathrm{Mm} \mid \mathrm{M}_{\mathrm{M}}=0, \mathrm{n}_{\mathrm{M}}=0, \mathrm{~b}_{\mathrm{M}}=1, v_{\mathrm{n}}}
\end{gathered}
$$

In models describing the torque of mechanical losses in a rotational hydraulic motor, used for description of losses and energy efficiency of the motor and of the hydrostatic transmission system in the $\left(0 \leq \bar{\omega}_{\mathrm{M}}<\bar{\omega}_{\mathrm{M} \max }, 0 \leq \overline{\mathrm{M}}_{\mathrm{M}}<\overline{\mathrm{M}}_{\mathrm{M} \max }\right)$ operating field, the increase of torque of mechanical losses occurring in fact at the motor speed $\mathrm{n}_{\mathrm{M}}$ approaching the zero value $\left(\mathrm{n}_{\mathrm{M}}=0\right)$ is not taken into account. That increase occurs below the shaft critical speed $\mathrm{n}_{\text {Mcr }}$. The motor rotational speed instability $\delta \mathrm{n}_{\mathrm{M}}$ increases below the critical speed $\mathrm{n}_{\mathrm{Mcr}}$ and in effect the torque $\mathrm{M}_{\mathrm{Mm}}$ of mechanical losses in the "shaft - working chambers" assembly increases. Assessment of the value of torque $\mathrm{M}_{\mathrm{Mm} \mid \mathrm{M}_{\mathrm{M}}=0, \mathrm{n}_{\mathrm{M}}=0, \mathrm{~b} \mathrm{~B}^{\mathrm{v}_{\mathrm{n}}}}$ of mechanical losses in a motor with zero rotational speed $\mathrm{n}_{\mathrm{M}}\left(\mathrm{n}_{\mathrm{M}}=0\right)$ is done by approximation of the function $\mathrm{M}_{\mathrm{Mm}_{\mathrm{M}} \mathrm{M}_{\mathrm{M}}=0, \mathrm{n}_{\mathrm{M}}, \mathrm{b}_{\mathrm{M}}, \mathrm{v}_{\mathrm{n}}}=\mathrm{f}\left(\mathrm{n}_{\mathrm{M}}\right)$ at $\mathrm{n}_{\mathrm{M}}=0$.

Exponent $\mathrm{a}_{v \mathrm{~m}}$ in expressions (7) and (9) determines the impact of the ratio $v / v_{n}$ of viscosity $v$ to the reference viscosity $v_{n}=35 \mathrm{~mm}^{2} \mathrm{~s}^{-1}$ of the working fluid on the value of torque of mechanical losses. The impact occurs mainly in a piston displacement machines with fluid filling the casing (in pumps and hydraulic motors).

The proposed theoretical model of the increase of torque $\Delta \mathrm{M}_{\mathrm{Mm} \mid \mathrm{M}_{\mathrm{M}}, \mathrm{n}_{\mathrm{M}^{\mathrm{b}}} \mathrm{b}_{\mathrm{M}}, \mathrm{v}}$ of mecha-nical losses in a rotational hydraulic motor, the increase resulting from loading the motor shaft with torque $M_{v}$, takes the same form in the case of a motor with theoretical (constant) capacity $q_{\mathrm{Mt}}$ per one shaft revolution $\left(b_{M}=1\right)$ and in the case of a motor with geometrical (variable) capacity $\mathbf{q}_{\mathrm{Mgv}}$ per one shaft revolution $\left(\mathrm{q}_{\mathrm{Mgv}}=\mathrm{b}_{\mathrm{M}} \mathrm{q}_{\mathrm{Mt}}\right)$ :

- in a hydraulic motor with theoretical (constant) capacity $\mathrm{q}_{\mathrm{Mt}}\left(\mathrm{b}_{\mathrm{M}}=1\right.$ ) per one shaft revolution (Fig. 1 and 3):

$$
\Delta \mathrm{M}_{\mathrm{Mm} \mid \mathrm{M}_{\mathrm{M}}, \mathrm{n}_{\mathrm{M}}, \mathrm{b}_{\mathrm{M}}=1, v}=
$$

$$
=\left(M_{M m \mid M_{M}=M_{M t}, n_{M}=n_{M t}, b_{M}=1, v_{n}}-M_{M m \mid M_{M}=0, n_{M}=n_{M t} b_{M}=1, v_{\mathrm{H}}}\right) \frac{M_{M}}{M_{M t}}
$$

- in a hydraulic motor with geometrical (variable) capacity $\mathrm{q}_{\mathrm{Mgv}}\left(\mathrm{q}_{\mathrm{Mgv}}=\mathrm{b}_{\mathrm{M}} \mathrm{q}_{\mathrm{Mt}}\right)$ per one shaft revolution (Fig. 4 and 5):

$$
\begin{gathered}
\Delta \mathrm{M}_{\mathrm{Mm} \mid \mathrm{M}_{\mathrm{M}}, \mathrm{n}_{\mathrm{M}}, \mathrm{b}_{\mathrm{M}}, v}= \\
=\left(\mathrm{M}_{\mathrm{Mm} \mid \mathrm{M}_{\mathrm{M}}=\mathrm{M}_{\mathrm{Mt}}, \mathrm{n}_{\mathrm{M}}=\mathrm{n}_{\mathrm{Mt}} \mathrm{b}_{\mathrm{M}}=1, v_{\mathrm{n}}}-\mathrm{M}_{\mathrm{Mm} \mid \mathrm{M}_{\mathrm{M}}=0, \mathrm{n}_{\mathrm{M}}=\mathrm{n}_{\mathrm{Mt}} \mathrm{b}_{\mathrm{M}}=1, v_{\mathrm{M}}}\right) \frac{\mathrm{M}_{\mathrm{M}}}{\mathrm{M}_{\mathrm{Mt}}}
\end{gathered}
$$

In effect, the proposed theoretical models describing the torque $\mathrm{M}_{\mathrm{Mm}}$ of mechanical losses in a hydraulic rotational motor take the forms:

- in a hydraulic motor with theoretical (constant) capacity $\mathrm{q}_{\mathrm{Mt}}\left(\mathrm{b}_{\mathrm{M}}=1\right.$ ) per one shaft revolution (Fig. 3):

$$
\begin{aligned}
M_{M m \mid M_{M}, n_{M}, b_{M}=1, v}= & \left.M_{M m \mid M_{M}=0, n_{M}=0, b_{M}=1, v_{n}}+\left(M_{M m \mid M_{M}=0, n_{M}=n_{M t}, b_{M}=1, v_{n}}-M_{M m \mid M_{M}=0, n_{M}=0, b_{M}=1, v_{n}}\right) \frac{n_{M}}{n_{M t}}\right]\left(\frac{v}{v_{n}}\right)^{a_{v m}} \\
& +\left(M_{M m \mid M_{M}=M_{M t}, n_{M}=n_{M t}, b_{M}=1, v_{n}}-M_{M m \mid M_{M}=0, n_{M}=n_{M t}, b_{M}=1, v_{n}}\right) \frac{M_{M}}{M_{M t}}
\end{aligned}
$$

- in a hydraulic motor with geometrical (variable) capacity $\mathrm{q}_{\mathrm{Mgv}}\left(\mathrm{q}_{\mathrm{Mgv}}=\mathrm{b}_{\mathrm{M}} \mathrm{q}_{\mathrm{Mt}}\right.$ ) per one shaft revolution (Fig. 4 - with $\mathrm{n}_{\mathrm{Mt}}, v_{\mathrm{n}}$, Fig. 6 - with $\left.v_{\min }, v_{\mathrm{n}}, v_{\max }\right)$ :

$$
\begin{gathered}
M_{M m \mid M_{M}, n_{M}, b_{M}, v}=\left[M_{M m \mid M_{M}=0, n_{M}=0, b_{M}=1, v_{n}}+\left(M_{M m \mid M_{M}=0, n_{M}=n_{M t}, b_{M}=1, v_{n}}-M_{M m \mid M_{M}=0, n_{M}=0, b_{M}=1, v_{n}}\right) \frac{n_{M}}{n_{M t}} b_{M}\right]\left(\frac{v}{v_{n}}\right)^{a_{v m}} \\
+\left(M_{M m \mid M_{M}=M_{M t}, n_{M}=n_{M t}, b_{M}=1, v_{n}}-M_{M m \mid M_{M}=0, n_{M}=n_{M t}, b_{M}=1, v_{n}}\right) \frac{M_{M}}{M_{M t}}
\end{gathered}
$$




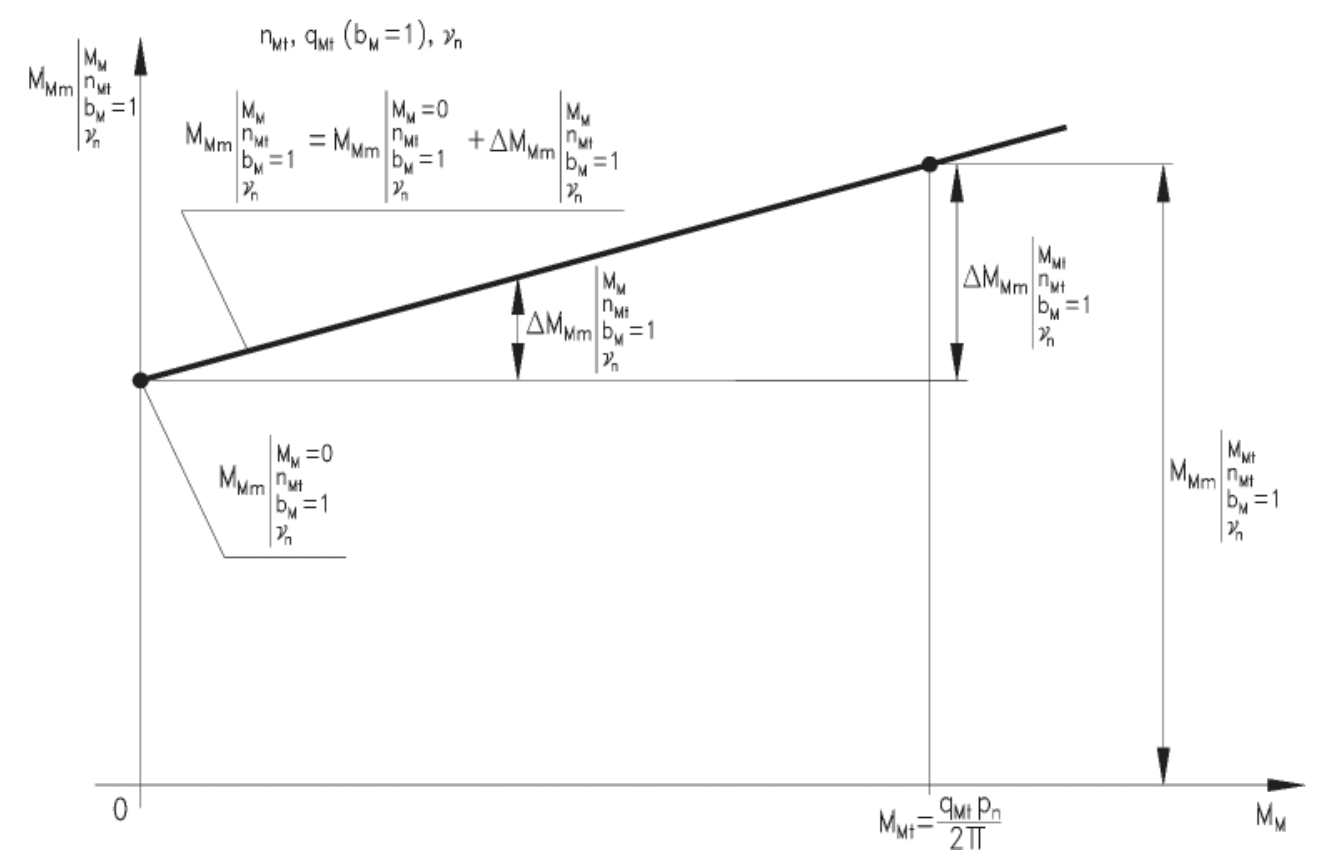

Fig. 1. Torque $M_{M m \mid M_{M}{ }^{n}{ }^{b}{ }^{b}{ }^{=1, v}{ }_{n}}$ of mechanical losses in the , shaft-working chambers" assembly of a rotational hydraulic motor with constant capacity $q_{M t}$ per one shaft revolution $\left(b_{M}=1\right)$, at the shaft theoretical rotational speed $n_{M t}$ and at the working fluid reference viscosity $v_{n}$, as a function of the motor shaft torque $M_{M}$ - graphical interpretation of the theoretical model (6)

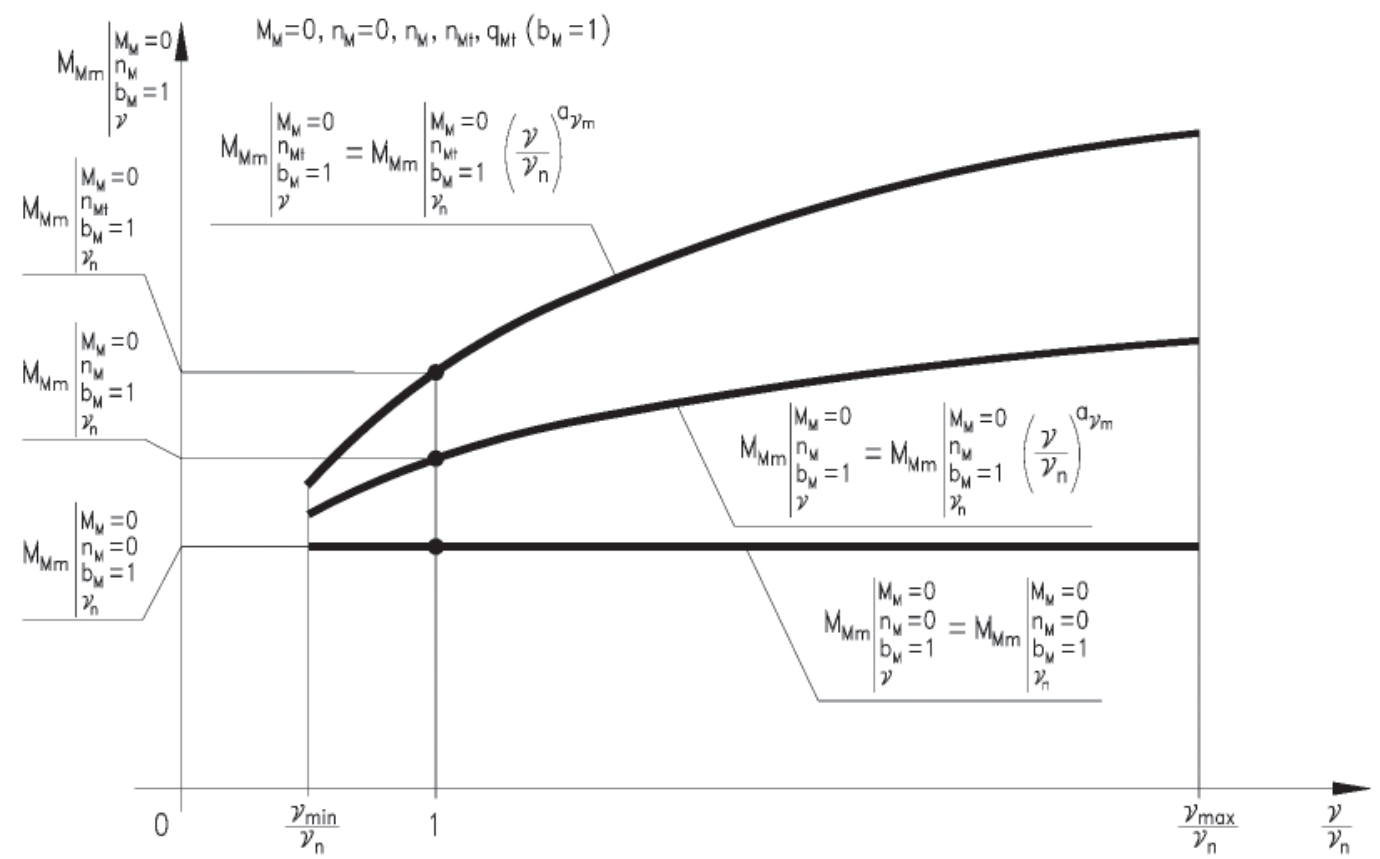

Fig. 2. Torque $M_{M m \mid M_{M}=0, n_{M}{ }^{b}=1, v}$ of mechanical losses in the ,shaft-working chambers” assembly of a rotational hydraulic motor with constant capacity $q_{M t}$ per one shaft revolution $\left(b_{M}=1\right)$, at shaft torque $M_{M}=0$, as a function of the ratio $v / v_{n}$ of viscosity $v$ to the working fluid reference viscosity $v_{n}-$ graphical interpretation of the theoretical models (7) and (8); motor shaft speeds: $n_{M}=0, n_{M} n_{M i}$. The impact of working fluid viscosity $v$ on friction forces between the , shaft-working chambers" assembly elements and the working fluid occurs mainly in the piston hydraulic motors with casing filled with the working fluid.

\section{MATHEMATICAL MODELS OF THE TORQUE OF MECHANICAL LOSSES}

In mathematical models describing the torque $M_{M m}$ of mechanical losses in a hydraulic rotational motor coefficients $k_{i}$ of losses are used relating (comparing) the components describing the torque $\mathrm{M}_{\mathrm{Mm}}$ of losses in theoretical models to the following reference values:

- theoretical torque $\mathrm{M}_{\mathrm{Mt}}=\frac{\mathrm{q}_{\mathrm{Mt}} \mathrm{p}_{\mathrm{n}}}{2 \Pi}$ of a hydraulic motor with theoretical (constant) capacity $\mathrm{q}_{\mathrm{Mt}}$ per one shaft resolution, determined at the decrease of $\Delta \mathrm{p}_{\mathrm{M}}$ of pressure in the motor equal to the system nominal pressure $\mathrm{p}_{\mathrm{n}}\left(\Delta \mathrm{p}_{\mathrm{M}}=\mathrm{p}_{\mathrm{n}}\right)$ and with assumption that there are no pressure and mechanical losses in the motor,

- theoretical rotational speed $\mathrm{n}_{\mathrm{Mt}}$ of a hydraulic motor with constant capacity $\mathrm{q}_{\mathrm{Mt}}$ per one shaft revolution resulting from the motor capacity $\mathrm{Q}_{\mathrm{M}}$ equal to the theoretical pump $\mathrm{Q}_{\mathrm{Pt}}\left(\mathrm{n}_{\mathrm{Mt}}=\frac{\mathrm{Q}_{\mathrm{Pt}}}{\mathrm{q}_{\mathrm{Mt}}}\right)$,

- theoretical capacity $\mathrm{Q}_{\mathrm{Pt}}$ of the hydraulic motor driving pump - a product of the theoretical capacity $\mathrm{q}_{\mathrm{pt}}$ per one shaft revolution of the constant capacity pump and the shaft speed $\mathrm{n}_{\mathrm{P} 0}$ of an unloaded pump $\left(\mathrm{Q}_{\mathrm{Pt}}=\mathrm{q}_{\mathrm{Pt}} \mathrm{n}_{\mathrm{P} 0}\right)$. 


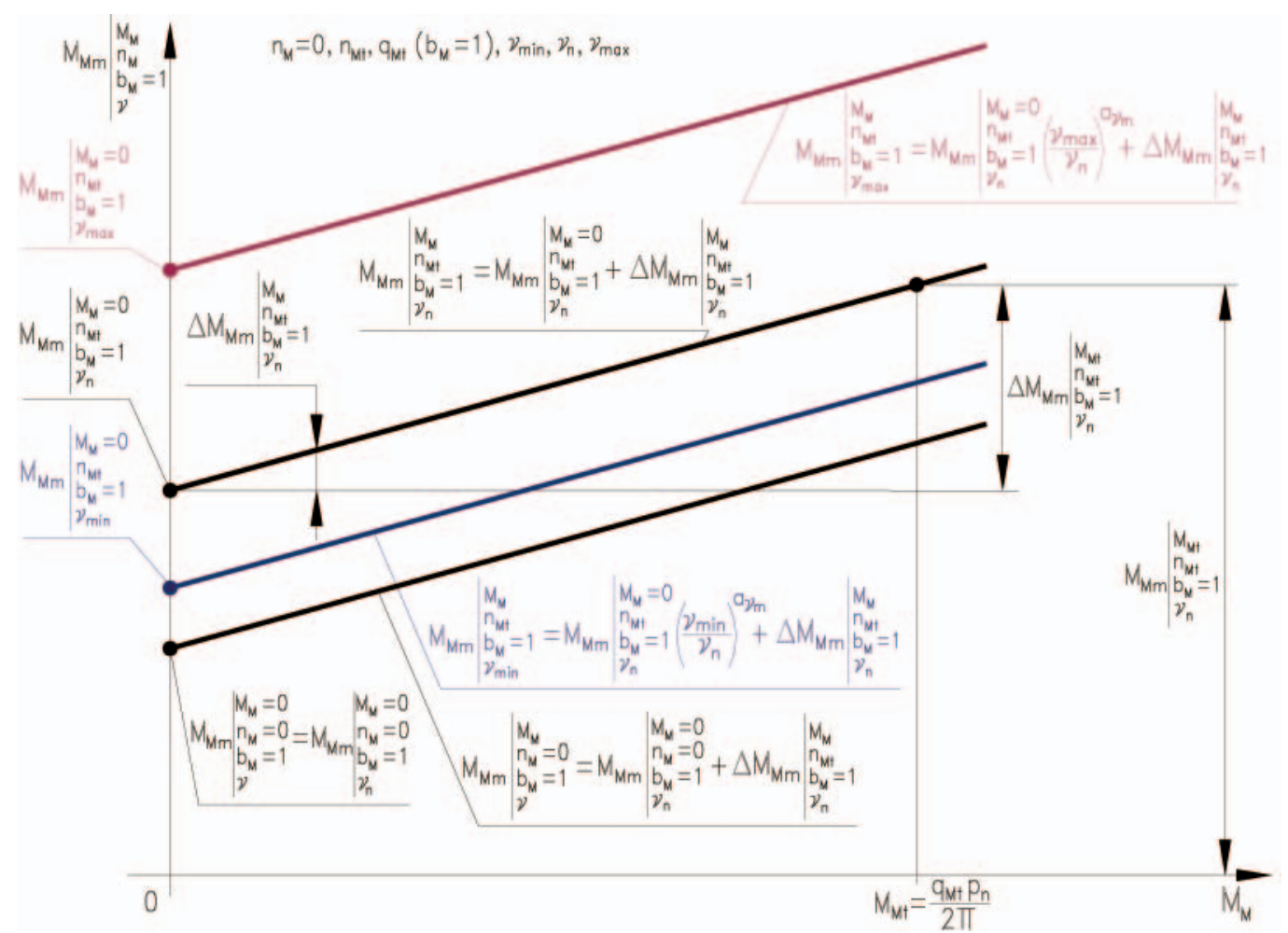

Fig. 3. Torque $M_{M m \mid M_{M}{ }^{n} M^{b} M^{\prime}=1, v}$ of $m$ echanical losses in the , shaft-working chambers" assembly of a rotational hydraulic motor with constant capacity $q_{M t}$ per one shaft revolution $\left(b_{M}=1\right)$, as a function of the motor shaft torque $M_{M}$ - graphical interpretation of the theoretical model (13); motor shaft speeds: theoretical speed $n_{M P}, n_{M}=0$; working fluid viscosity $v_{\text {min }}$, $v_{n}$ and $v_{\text {max }}$. The impact of working fluid viscosity $v$ on friction forces between the , shaft - working chambers" assembly elements and the working fluid occurs mainly in the piston hydraulic motors with casing filled with the working fluid.

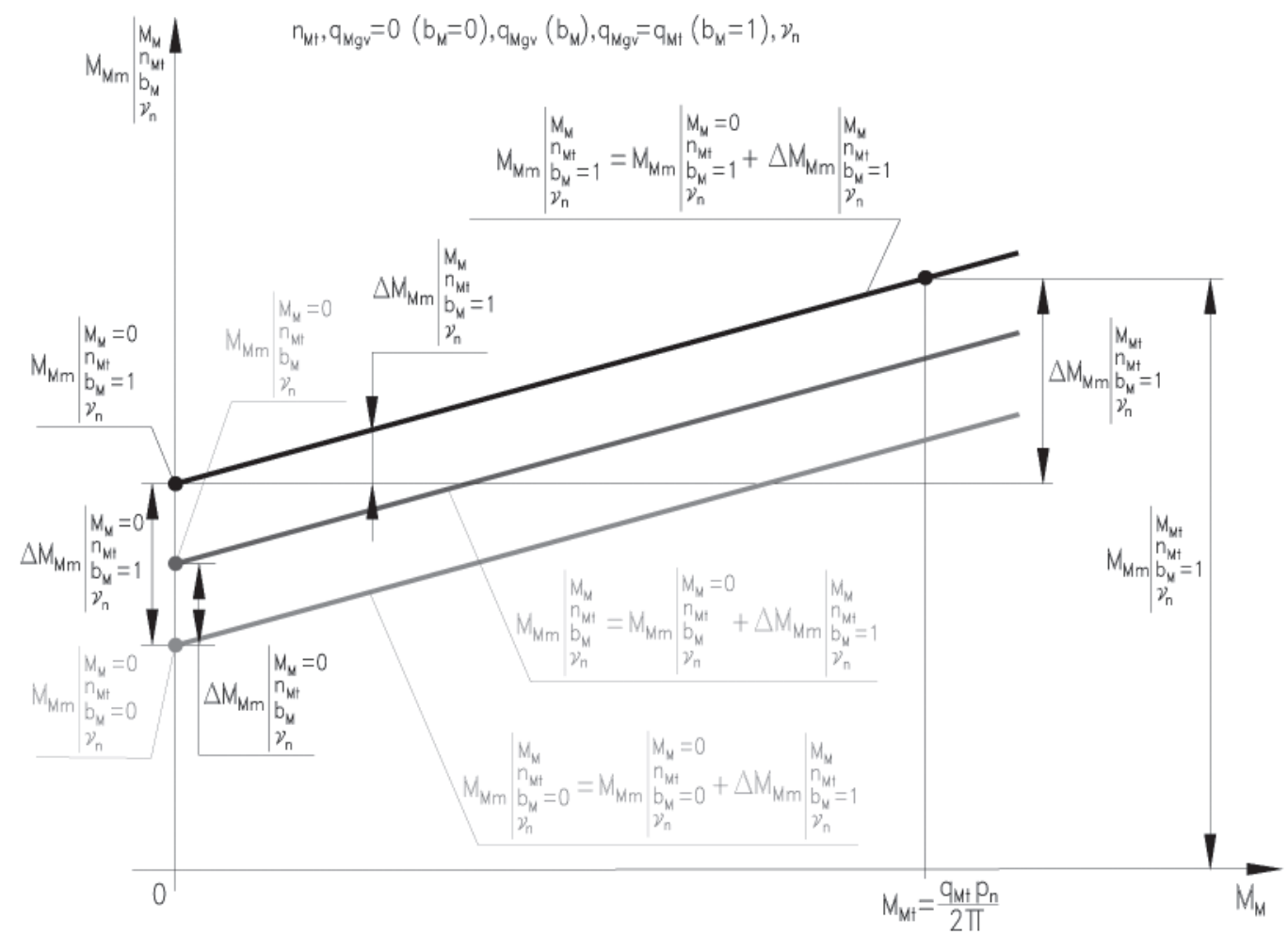

Fig. 4. Torque $M_{M m \mid M_{M}{ }^{n}{ }^{b}{ }^{b}{ }_{n}^{v}}$ of mechanical losses in the ,shaft-working chambers” assembly of a rotational hydraulic motor with variable capacity $q_{M g v}=b_{M} q_{M t}$ per one shaft revolution, at theoretical shaft rotatio-nal speed $n_{M t}$ and at working fluid reference viscosity $v_{n}$, as a function of the motor shaft torque $M_{M}$ - graphical interpretation of the theoretical model (14); capacity $q_{M g v}$ per one shaft revolution (coefficient $b_{M}{ }^{n}$ of the change of capacity per one shaft revolution): $q_{M g v}=0\left(b_{M}=0\right), q_{M g v}\left(b_{M}\right), q_{M g v}=q_{M t}\left(b_{M}=1\right)$

Theoretical and mathematical models describe the torque $\mathrm{M}_{\mathrm{Mm}}$ of mechanical losses in a rotational hydraulic motor with theoretical (constant) capacity $\mathrm{q}_{\mathrm{Mt}}$ per one shaft revolution or with geometrical (variable) capacity $\mathrm{q}_{\mathrm{Mgv}}=\mathrm{b}_{\mathrm{M}} \mathrm{q}_{\mathrm{Mt}}$ per one shaft revolution:
- $\mathrm{q}_{\mathrm{Mt}}=\mathrm{q}_{\mathrm{M} \backslash \Delta \mathrm{p}_{\mathrm{Mi}}=0, \mathrm{p}_{\mathrm{M} 2}=0, \mathrm{v}_{\mathrm{n}}}$ is a theoretical capacity per one shaft resolution of a constant ca-pacity motor, determined at $\Delta \mathrm{p}_{\mathrm{Mi}}=0, \mathrm{p}_{\mathrm{M} 2 \mathrm{i}}=0$ and $v_{\mathrm{n}}$, which is equal to the theoretical active volume of the working chambers during one shaft revolution, 


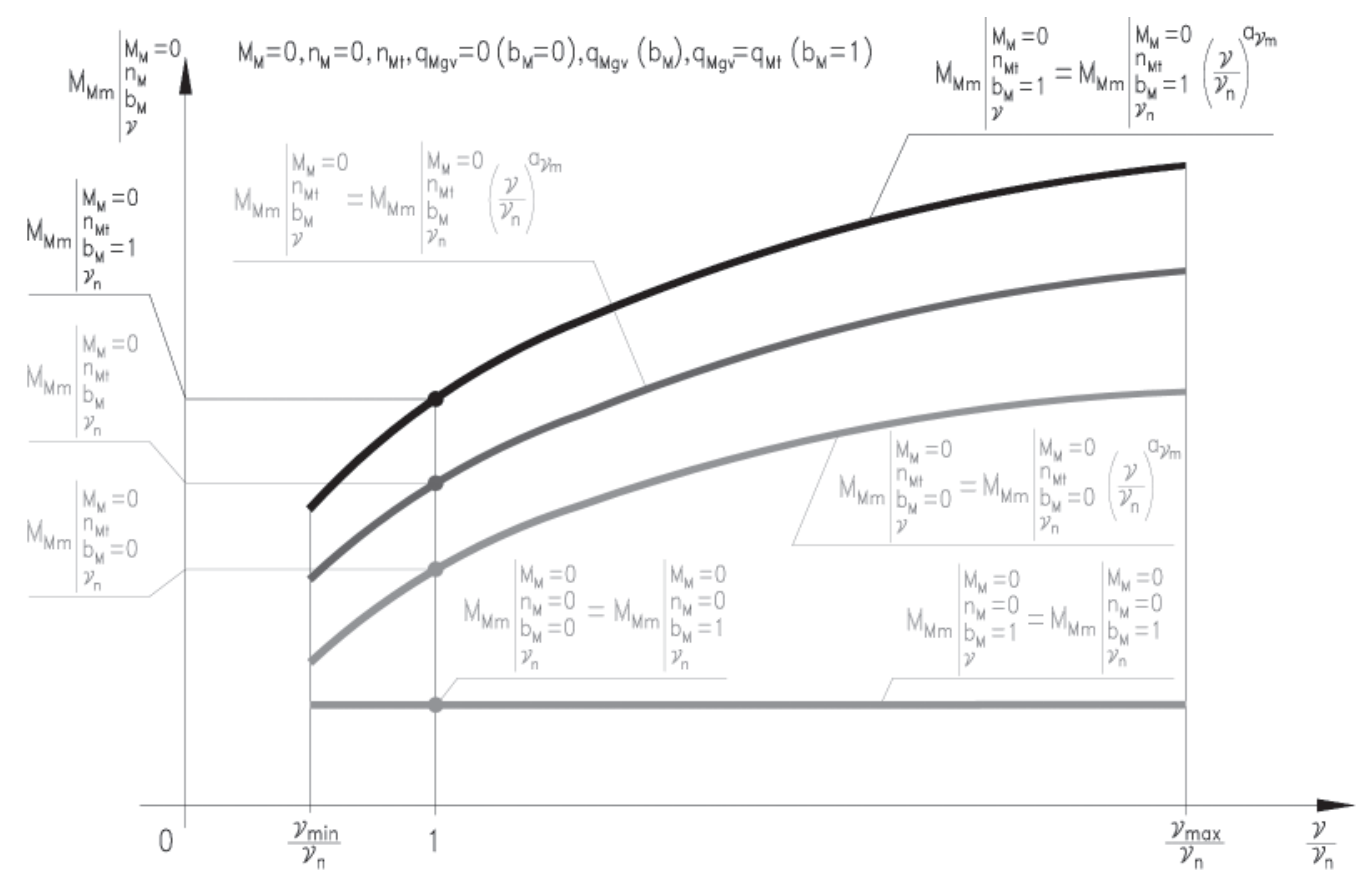

Fig. 5. Torque $M_{M m \mid M_{M}=0, n^{b}{ }^{v}{ }^{v}}$ of mechanical losses in the ,shaft - working chambers” assembly of a rotational hydraulic motor with variable capacity

$q_{M g v}=b_{M} q_{M t}$ per one shaft resolution, at the shaft torque $M_{M}=0$ as a function of the ratio $v / v_{n}$ of viscosity $v$ to the working fluid reference viscosity $v_{n}$ - graphical interpretation of the theoretical models (9) and (10); motor shaft speeds: theoretical speed $n_{M P}, n_{M}=0$; capacity $q_{M g v}$ per one shaft revolution (coefficient $b_{M}$ of the change of capacity per one shaft revolution)): $q_{M v v}=0\left(b_{M}=0\right), q_{M g v}=\left(b_{M}\right), q_{M v v}=q_{M t}\left(b_{M}=1\right)$. The impact of working fluid viscosity $v$ on friction forces between the , shaft-working chambers” assembly elements and the working fluid occurs mainly in the piston hydraulic motors with casing filled with the working fluid.

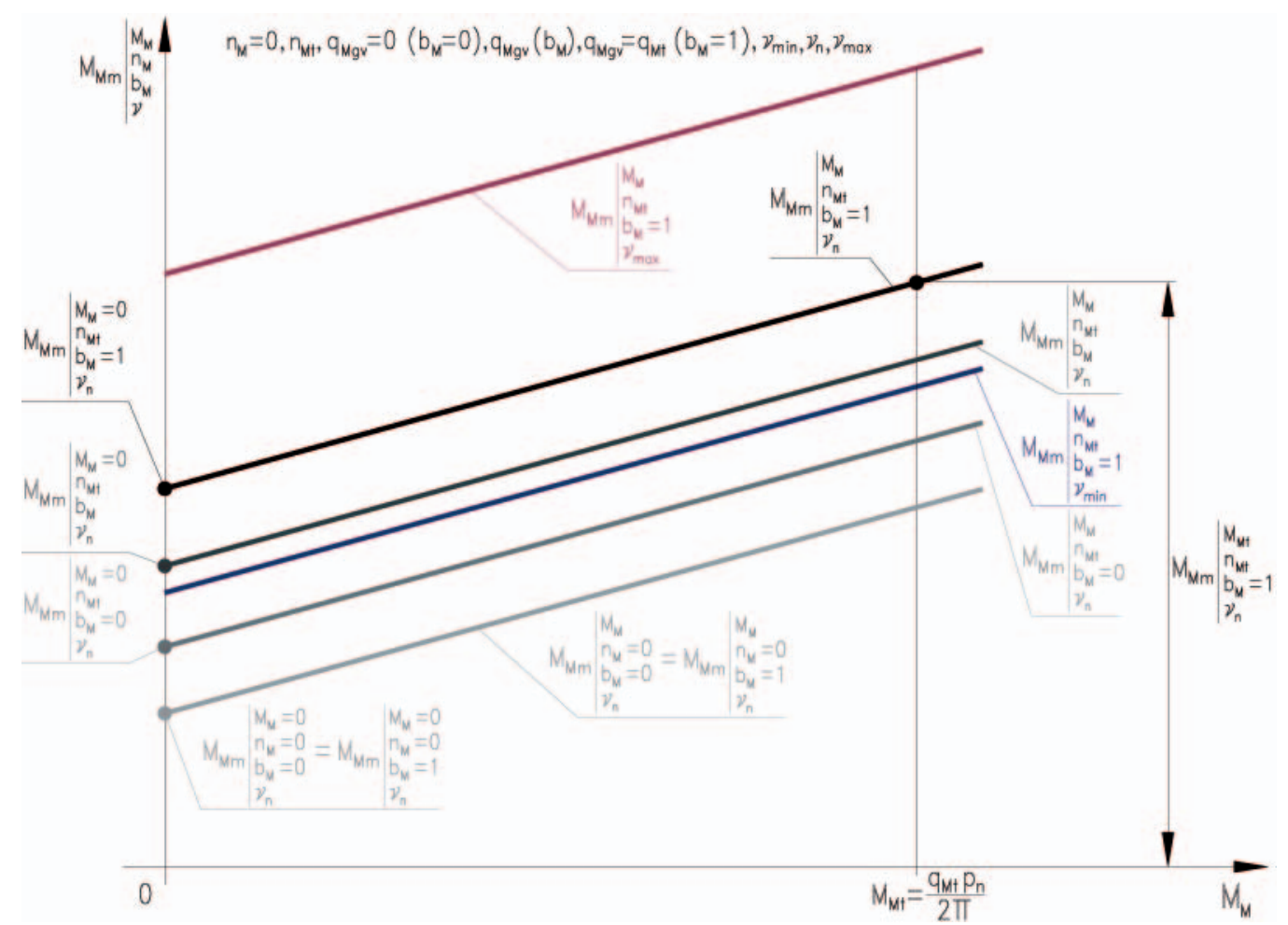

Fig. 6. Torque $M_{M m \mid M_{M^{n} M^{b}{ }^{v}}}$ of mechanical losses in the ,shaft-working chambers” assembly of a rotational hydraulic motor with variable capacity $q_{M g v}=b_{M} q_{M t}$ per one shaft revolution as a function of the motor shaft torque $M_{M}$-graphical interpretation of the theoretical model (14); motor shaft speeds:

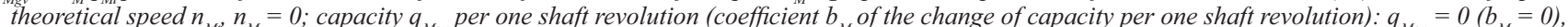
$q_{M g v}\left(b_{M}\right), q_{M g v}=q_{M t}\left(b_{M}=1\right)$. The impact of working fluid viscosity $v$ on friction forces between the , shaft - working chambers" assembly elements and the working fluid occurs mainly in the piston hydraulic motors with casing filled with the working fluid

- $\mathrm{q}_{\mathrm{Mgv}}=\mathrm{b}_{\mathrm{M}} \mathrm{q}_{\mathrm{MI}}$ is a geometrical capacity per one shaft revolution of a variable capacity motor, determined at $\Delta \mathrm{p}_{\mathrm{Mi}}=0, \mathrm{p}_{\mathrm{M} 2 \mathrm{i}}=0$ and $v_{\mathrm{n}}$, which is equal to the geometrical active volume of the working chambers during one shaft revolution. In developing the models it is assumed that capacity $\mathrm{q}_{\mathrm{Mgv}}$ per one hydraulic motor shaft revolution changes in the $0 \leq \mathrm{q}_{\mathrm{Mgv}} \leq \mathrm{q}_{\mathrm{Mt}}$ range and coefficient $\mathrm{b}_{\mathrm{M}}=\mathrm{q}_{\mathrm{Mgv}} / \mathrm{q}_{\mathrm{Mt}}$ of the variation of capacity per one motor shaft revolution changes in the $0 \leq \mathrm{b}_{\mathrm{M}} \leq 1$ range.

The proposed mathematical models describing the torque $\mathrm{M}_{\mathrm{Mm}}$ of mechanical losses in the ,shaft - working chambers" assembly, related to the theoretical models of the torque of mechanical losses, take the form: 
- in a hydraulic motor with theoretical (constant) capacity $\mathrm{q}_{\mathrm{Mt}}$ $\left(\mathrm{b}_{\mathrm{M}}=1\right)$ per one shaft revolution [referring to theoretical model (13)]:

$$
\begin{gathered}
\mathrm{M}_{\mathrm{Mm} \mid \mathrm{M}_{\mathrm{M}}, \mathrm{n}_{\mathrm{M}}, \mathrm{b}_{\mathrm{M}}=1, v}=\left(\mathrm{k}_{7.1 .1}+\mathrm{k}_{7.1 .2} \frac{\mathrm{n}_{\mathrm{M}}}{\mathrm{n}_{\mathrm{Mt}}}\right) \mathrm{M}_{\mathrm{Mt}}\left(\frac{v}{v_{\mathrm{n}}}\right)^{\mathrm{a}_{\mathrm{vm}}}+ \\
+\mathrm{k}_{7.2} \mathrm{M}_{\mathrm{M}}=\left(\mathrm{k}_{7.1 .1}+\mathrm{k}_{7.1 .2} \frac{\mathrm{n}_{\mathrm{M}}}{\mathrm{n}_{\mathrm{Mt}}}\right) \frac{\mathrm{q}_{\mathrm{Mt}} \mathrm{p}_{\mathrm{n}}}{2 \Pi}\left(\frac{v}{v_{\mathrm{n}}}\right)^{\mathrm{a}_{\mathrm{vm}}}+\mathrm{k}_{7.2} \mathrm{M}_{\mathrm{M}}
\end{gathered}
$$

where:

$$
\mathrm{k}_{7.1 .1}=\frac{\mathrm{M}_{\mathrm{Mm} \mid \mathrm{M}_{\mathrm{M}}=0, \mathrm{n}_{\mathrm{M}}=0, \mathrm{~b}_{\mathrm{M}}=1, v_{\mathrm{n}}}}{\mathrm{M}_{\mathrm{Mt}}}=\frac{\mathrm{M}_{\mathrm{Mm} \mid \mathrm{M}_{\mathrm{M}}=0, \mathrm{n}_{\mathrm{M}}=0, \mathrm{~b}_{\mathrm{M}}=1, v_{\mathrm{n}}}}{\frac{\mathrm{q}_{\mathrm{Mt}} \mathrm{p}_{\mathrm{n}}}{2 \Pi}}
$$

$$
\mathrm{k}_{7.1 .2}=\frac{\mathrm{M}_{\mathrm{Mm} \mid \mathrm{M}_{\mathrm{M}}=0, \mathrm{n}_{\mathrm{M}}=\mathrm{n}_{\mathrm{Mt}}, \mathrm{b}_{\mathrm{M}}=1, v_{\mathrm{n}}}-\mathrm{M}_{\mathrm{Mm} \mid \mathrm{M}_{\mathrm{M}}=0, \mathrm{n}_{\mathrm{M}}=0, \mathrm{~b}_{\mathrm{M}}=1, v_{\mathrm{n}}}}{\mathrm{M}_{\mathrm{Mt}}}=
$$$$
=\frac{M_{M m \mid M_{M}=0, n_{M}=n_{M t}, b_{M}=1, v_{n}}-M_{M m \mid M_{M}=0, n_{M}=0, b_{M}=1, v_{n}}}{\frac{\mathrm{q}_{M t} p_{n}}{2 \Pi}}
$$

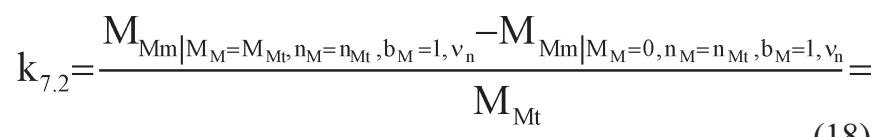$$
=\frac{M_{M m \mid M_{M}=M_{M t}, n_{M}=n_{M t}, b_{M}=1, v_{n}}-M_{M m \mid M_{M}=0, n_{M}=n_{M t}, b_{M}=1, v_{n}}}{\frac{\mathrm{q}_{M t} p_{n}}{2 \prod}}
$$

- in a hydraulic motor with geometrical (variable) capacity $\mathrm{q}_{\mathrm{Mgv}}\left(\mathrm{q}_{\mathrm{Mgv}}=\mathrm{b}_{\mathrm{M}} \mathrm{q}_{\mathrm{Mt}}\right)$ per one shaft revolution [referring to theoretical model (14)]:

$$
\begin{gathered}
\mathrm{M}_{\mathrm{Mm} \mid \mathrm{M}_{\mathrm{M}}, \mathrm{n}_{\mathrm{M}}, \mathrm{b}_{\mathrm{M}}, v}=\left(\mathrm{k}_{7.1 .1}+\mathrm{k}_{7.1 .2} \frac{\mathrm{n}_{\mathrm{M}}}{\mathrm{n}_{\mathrm{Mt}}} \mathrm{b}_{\mathrm{M}}\right) \mathrm{M}_{\mathrm{Mt}}\left(\frac{\mathrm{v}}{v_{\mathrm{n}}}\right)^{\mathrm{a}_{\mathrm{vm}}}+ \\
+\mathrm{k}_{7.2} \mathrm{M}_{\mathrm{M}}=\left(\mathrm{k}_{7.1 .1}+\mathrm{k}_{7.1 .2} \frac{\mathrm{n}_{\mathrm{M}}}{\mathrm{n}_{\mathrm{Mt}}} \mathrm{b}_{\mathrm{M}}\right) \frac{\mathrm{q}_{\mathrm{Mt}} \mathrm{p}_{\mathrm{n}}}{2 \Pi}\left(\frac{v}{v_{\mathrm{n}}}\right)^{\mathrm{a}_{\mathrm{vm}}}+\mathrm{k}_{7.2} \mathrm{M}_{\mathrm{M}}
\end{gathered}
$$

where: coefficient $\mathrm{k}_{7.1 .1}$ is described by expression (16), coefficient $\mathrm{k}_{7.1 .2}$ - by expression (17), coefficient $\mathrm{k}_{7.2}$ - by expression (18).

\section{CONCLUSIONS}

1. Theoretical and mathematical models have been developed of the torque $\mathrm{M}_{\mathrm{Mm}}$ of mechanical losses in the ,shaft - working chambers" assembly of a rotational hydraulic motor with constant $\mathrm{q}_{\mathrm{Mt}}\left(\mathrm{V}_{\mathrm{Mt}}\right)$ and with variable $\mathrm{q}_{\mathrm{Mgv}}\left(\mathrm{V}_{\mathrm{Mgv}}\right)$ capacity per one motor shaft revolution.

The models present dependence of the torque $\mathrm{M}_{\mathrm{Mm}}$ of mechanical losses in the assembly on the torque $\mathrm{M}_{M}$ loading the shaft and on the shaft speed $\mathrm{n}_{\mathrm{M}}$ [changing in the $\left(0 \leq \overline{\mathrm{M}}_{\mathrm{M}}<\overline{\mathrm{M}}_{\mathrm{Mmax}}, 0 \leq \bar{\omega}_{\mathrm{M}}<\bar{\omega}_{\mathrm{Mmax}}\right)$ motor (and the hydrostatic transmission system) operating range] and also on the working fluid viscosity $v$ changing in the $v_{\min } \leq v \leq v_{\max }$ range. Torque $\mathrm{M}_{\mathrm{M}}$, shaft speed $\mathrm{n}_{\mathrm{M}}$ and working fluid viscosity $v$ are independent of the motor and of the losses in it.

The models present also the dependence of torque $\mathrm{M}_{\mathrm{Mm}}$ on the capacity $\mathrm{q}_{\mathrm{Mgv}}$ per one shaft revolution (coefficient
$\mathrm{b}_{\mathrm{M}}=\mathrm{q}_{\mathrm{Mgv}} / \mathrm{q}_{\mathrm{Mt}}$ of the capacity per one shaft revolution) in a variable capacity motor. In the models, the change of $\mathrm{q}_{\mathrm{Mgv}}$ $\left(\mathrm{b}_{\mathrm{M}}\right)$ is assumed in the $0 \leq \mathrm{q}_{\mathrm{Mgv}} \leq \mathrm{q}_{\mathrm{Mt}}\left(0 \leq \mathrm{b}_{\mathrm{M}} \leq 1\right)$ range, although during the motor operation $b_{\mathrm{Mmin}}$ is of the order of $0.2 \div 0.3$.

2. Mathematical models of the torque $\mathrm{M}_{\mathrm{Mm}}$ of mechanical losses are based on the defined coefficients $\mathrm{k}_{\mathrm{i}}$ of energy losses, relating the torque of mechanical losses to the reference values:

- theoretical torque $\mathrm{M}_{\mathrm{Mt}}$ of the motor with theoretical (constant) capacity $\mathrm{q}_{\mathrm{Mt}}$ per one shaft revolution determined at the system nominal pressure $\mathrm{p}_{\mathrm{n}}$,

- theoretical rotational speed $\mathrm{n}_{\mathrm{Mt}}$ of the motor with theoretical (constant) capacity $\mathrm{q}_{\mathrm{Mt}}$ per one shaft revolution resulting from the pump theoretical capacity $\mathrm{Q}_{\mathrm{Pt}}$.

3. Mathematical models of the torque $\mathrm{M}_{\mathrm{Mm}}$ of mechanical losses in the "shaft - working chambers" assembly should correspond with models of volumetric losses in the motor working chambers and with models of pressure losses in the motor channels.

\section{BIBLIOGRAPHY}

1. Paszota Z.: Graphical presentation of the power of energy losses and power developed in the elements of hydrostatic drive and control system. Part I - Rotational hydraulic motor speed series throttling control systems. Chapter in the monograph: ,Research, design, production and operation of hydraulic systems" (in Polish), Adam Klich, Edward Palczak and Andrzej Meder editors. „Cylinder” Library. Komag Mining Mechanisation Centre, Gliwice 2008

2. Paszota Z.: Graphical presentation of the power of energy losses and power developed in the elements of hydrostatic drive and control system. Part II - Rotational hydraulic motor speed parallel throttling control and volumetric control systems. Chapter in the monograph: „Research, design, production and operation of hydraulic systems" (in Polish), Adam Klich, Edward Palczak and Andrzej Meder editors. „Cylinder” Library. Komag Mining Mechanisation Centre, Gliwice 2008

3. Paszota Z.: Direction of increase of power stream in the hydrostatic drive and control system. Graphical presentation of the power of energy losses and power developed in the elements of hydrostatic drive and control system. Part I - Rotational hydraulic motor speed series throttling control systems. (in Polish), Napędy i sterowanie, scientific monthly, No 10 (114), October 2008

4. Paszota Z.: Direction of increase of power stream in the hydrostatic drive and control system. Graphical presentation of the power of energy losses and power developed in the elements of hydrostatic drive and control system. Part II - Rotational hydraulic motor speed parallel throttling control and volumetric control systems. (in Polish), Napędy i sterowanie, scientific monthly, No 11 (115), November 2008

5. Paszota Z:: Graphical presentation of the power of energy losses and power developed in the elements of hydrostatic drive and control system. Part I - Rotational hydraulic motor speed series throttling control systems. Polish Maritime Research 03/2008

6. Paszota Z.: Graphical presentation of the power of energy losses and power developed in the elements of hydrostatic drive and control system. Part II - Rotational hydraulic motor speed parallel throttling control and volumetric control systems. Polish Maritime Research 04/2008

7. Paszota Z.: The operating field of a hydrostatic drive system. Chapter in the monograph: „Research, design, production and operation of hydraulic systems" (in Polish), Adam Klich, Antoni Kozieł and Edward Palczak editors. „Cylinder” Library. Komag Mining Mechanisation Centre, Gliwice 2009 
8. Paszota Z.: Parameters of the energy efficiency investigations of pumps and hydraulic motors. The operating field of a hydrostatic drive system. (in Polish), Napędy i sterowanie, scientific monthly, No 11 (127), November 2009

9. Paszota Z.: The operating field of a hydrostatic drive system parameters of the energy efficiency investigations of pumps and hydraulic motors. Polish Maritime Research 04 / 2009

10.Paszota Z.: Energy losses in the hydraulic rotational motordefinitions and relations for evaluation of the efficiency of motor and hydrostatic drive. Polish Maritime Research 02/2010.

\section{CONTACT WITH THE AUTHOR}

Prof. Zygmunt Paszota Faculty of Ocean Engineering and Ship Technology

Gdansk University of Technology Narutowicza 11/12

80-233 Gdansk, POLAND

e-mail: zpaszota@pg.gda.pl 